conditions of formation of readiness of future reserve officers for military service]. Innovative pedagogy. issue. 9. Vol. 2. pp. 61-68. [in Ukrainian].

8. Pro zatverdzhennia Instruktsii pro orhanizatsiiu viiskovoi pidhotovky hromadian Ukrainy za prohramoiu pidhotovky ofitseriv zapasu: nakaz Minoborony Ukrainy, MON Ukrainy vid 14.12.2015 r. № 719/1289 [Approval of the Instruction on the Organization of Military Training of Ukrainian Citizens under the Reserve Officers Training Program: Minister of Defense order, Ministry of Defense of Ukraine, 14.12.2015. № 719/1289]. Available at: http:// zakon4.rada.gov.ua/laws/show/z1678-15/page (accessed 15 Apr.2019). [in Ukrainian].

9. Sergienko, T. N., Medvid, M. M. \& Ryutin, V. V. (2018). Model sotsialnopedagogicheskoy profilaktiki dezadaptatsii kursantov mladshikh kursov vysshikh voennykh uchebnykh zavedeniy i analiz rezultatov eksperimenta po ee vnedreniyu [Model of sociopedagogical prevention of maladaptation of younger cadets of higher military educational institutions and analysis of the results of the experiment on its introduction]. Wschonioeuropejskie Czasopismo Naukowe. No.3 (31), 5. pp. 29-39.[in Russian].

10. Sinkevych, S. V. (2013). Metodychni zasady indyvidualizatsii navchannia maibutnikh ofitseriv zapasu [Methodical principles of individualization of training of future reserve officers]. Collection of scientific works of the National Academy of State Border Guard Service of Ukraine. Pedagogical and psychological sciences. No. 1. pp. 269-276. [in Ukrainian].

Стаття надійшла до редакції 10.10.2019

УДК: $791: 398$ (477) “20”

DOI:

Катерина Степаненко, асистент кафедри тележурналістики та майстерності актора Київського начіонального університету культури і мистеитв

\title{
ВІДРОДЖЕННЯ ФОЛЬКЛОРНОЇ СТИЛІСТИКИ В УКРАЇНСЬКОМУ КІНО 2000-Х РОКІВ
}

У статті розглянуто проиес відродження фольклорної стилістки у вітчизняному кінематографi, який відбувся на початку 2000-х років. Доведено, щзо проаналізовані художні фільми (в тому числі, короткометражні кінокартини та документалістика) набули таких важливих елементів кінопоетики, як автентичний спів, народні танці, фольклорна музика, використання різноманітних діалектів украӥнської мови, натуралістичність зйомок, живописний візуальний ряд тощьо.

Ключові слова: поетичне кіно; фольклорна стилістка; украӥнський кінематограф.

Jim. 15.

Kateryna Stepanenko, Assistant Professor of the Television Journalism and Acting Department Kyiv National University of Culture and Arts

\section{REVIVAL OF FOLKLORE STYLISTICS IN THE UKRAINIAN MOVIE IN 2000-S}

The article deals with the process of revival of folklore stylist in domestic cinema, which took place in the early 2000s. The paper points out that during the 1960s and 1970s Ukrainian moviegoers suffered almost the greatest number in the second half of the twentieth century harassment by official Soviet power. Most films of the notorious poetic direction, started by director S. Paradzhanov and continued by his colleagues and associates $-L$. Osika, V. Denysenko, Y. Illenko, M. Maschenko, I. Mykolaychuk and other artists, were banned; much of the interesting ideas were not realized.

With the beginning of the 1990s and the gaining of independence by Ukraine, the situation began to change gradually: the focus of attention of domestic writers and directors was the history of Ukraine, in particular the pages of its previously forbidden chronicle; a new original reading of Ukrainian literary classics appeared, involving many ethnographic components in the film process; there was a revival of the mystical and folklore trend in cinema.

Initiated in the 1990s, the processes intensified in the early 2000s and continue to strengthen in our time. In particular, a number of feature films have been released into Ukrainian cinema, in which the naturalistic nature of the shoots, the picturesque visual series, the attraction of authentic music, folk dances, the use of various dialects of the Ukrainian language, the reliance on literary classics and other stylistic features, have directed them to poetic folk. Philosophical understanding of the surrounding world, rooted in the sources of folk wisdom, was observed in short films and national documentary, which continued the development of stylistics of Ukrainian folk film school in the mid-twentieth century.

Keywords: poetic cinema; folklore stylist; Ukrainian cinematography.

П остановка проблеми. 3 історії вітчизняного кінематографа відомо, що продовж 1960 - 1970-х років українські кіномитці зазнали чи не найбільших у другій половині XX століття утисків з боку офіційної влади. Більшість фільмів славнозвісного поетичного напряму, започаткованого режисером С. Параджановим і продовженого його колегами 
й однодумцями - Л. Осикою, В. Денисенком, Ю. Іллєнком, М. Мащенком, І. Миколайчуком та іншими митцями, були заборонені; значна частина цікавих задумів не була втілена. В результаті, поетичний напрям з його яскравою зображальною, фольклорною стилістикою опинився за межами дозволеного державною ідеологією.

3 початком 1990-х років й здобуттям Україною незалежності, ситуація почала поступово змінюватися: в центрі уваги вітчизняних сценаристів і режисерів знов опинилася історія України, зокрема сторінки її забороненого літопису; з'явилося нове оригінальне прочитання української літературної класики із залученням у кінопроцес багатьох етнографічних складових; відбулося відродження містично-фольклорного напряму у кіномистецтві. Започатковані процеси активізувалися на початку 2000-х років й продовжують посилюватися у наш час. Про що, зокрема свідчить поява низки кінокартин, які отримали широкий резонанс як серед вітчизняного, так і зарубіжного глядача. Акуальність дослідження зумовлена зростанням кінознавчого інтересу до творчих процесів, що відбуваються у сучасному українському кінематографі.

Аналіз основних досліджень і публікацій довів, що проблема розвитку українського кінематографу періоду незалежності неодноразово висвітлювалася у монографіях та наукових публікаціях вітчизняних кінознавців Л. Брюховецької [1, 77 - 84], [2, 4 - 5], [3], Р. Бучка [4, 415 - 421], С. Дяченка[5, 109], І.Зубавіної[6],Н.Капельгородської [8], В. Кузьмука [10, 227 - 231], О. Мусієнко [11, 186 - 193], О. Рутковського [13, 202 - 213]. Авторами було висвітлено значення сучасного вітчизняного кіно як фактора національного самоствердження, встановлено місце України у сучасному кінематографічному світі, виявлено тенденції й вектори розвитку сучасного українського кіно, визначено провідних постатей (режисерів, операторів, сценаристів тощо), які впливають на формування кіностилістики початку XXI століття. Водночас відзначимо, що фольклорний напрям розвитку сучасного українського кіно був розглянутий вітчизняними кінознавцями досить побіжно. Останній факт зумовив наше зацікавлення даною проблематикою.

Мета статті полягає в аналізі процесу відродження й становлення фольклорної стилістики у вітчизняному кінематографі на сучасному етапі.

Виклад основного матеріалу. Отже, на початку 2000-х років в український кінопрокат вийшла низка фільмів, в яких натуралістичність зйомок, живописний візуальний ряд, залучення автентичної музики, опора на літературну класику та інші стилістичні ознаки, спрямовували їх до поетичного фольклорного напряму. Серед них були: “Akeldama. На полі крові” Я. Лупія (за творчістю Л. Українки, 2001), “Чорна рада”М.ЗасєєваРуденко (за мотивами однойменного твору П. Куліша, 2001), “Молитва за гетьмана Мазепу” Ю. Іллєнка (2001), “Мамай” О. Саніна (2003), “Остнанній гетьман” Р. Плахова-Модестова (2004), “Богдан Зиновій Хмельницький” М. Мащенка (три версії: 2005, 2007, 2008) тощо.

Так, у “Чорній раді” було осмислено українську історію часів Руїни, коли серед заможного козацтва відбувалася боротьба за владу. Значну частину картини знімали на натурі - в селі Парадівка у Васильківському районі під Київом (професійних акторів було залучено близько 1000 осіб (!). Творці фільму не лише намагалися уникнути історичних неточностей, а й дбайливо поставилися до літературного першоджерела (наприклад, всі діалогі твору П. Куліша залишили без переробок), досить реалістично відтворили побутові обставини, в яких діяли кіногерої. Єдиним відхилом, який дозволив собі М. Засєєв-Руденко, стало введення у фільм образу Богдана Хмельницького (у книзі цей персонаж відсутній). Режисер наполягав, що смерть гетьмана у 1657 році і перехід влади став найважливішою подією для розуміння глядачем тогочасного періоду української історії, адже через шість років козацтво почало поступово зникати $[12,4]$.

Режисером й автором сценарію фільму “Молитва за гетьмана Мазепу” став Юрій Іллєнко. Він запропонував власне трактування однієї 3 найяскравіших і загадкових особистостей української історії - військового, політичного та державного діяча Івана Мазепи. Поштовхом для створення кінофільму став факт анафеми, накладений на українського гетьмана. Не можна не погодитися із слушною думкою кінознавця В. Симака, який наголошував, що Іллєнко трактує анафему, як містичний вплив на долю всієї України; анафема мислиться ним як прокляття. “Це прокляття падає і на країну, яка майже на триста років втрачає державність. За Іллєнком виходить, що головний колективний досвід українського народу, закарбований в його підсвідомості - це життя під анафемою, прокляте життя..." [15].

Відомо, що прем'єра кінострічки спонукала вітчизняних та зарубіжних кінокритків до суперечки: у якій площині розглядати фільм - в “історичній” чи образній, метафоричній? Адже, 3 
одного боку, Іллєнко апелював до історичного наративу, з іншого, ставало очевидним, що вагоме місце посідав в ньому саме поетичний дискурс. Оригінальним у фільмі стало зіткнення різних змістовних векторів, які певною мірою розривали історичне тло кінокартини. Приміром, самого гетьмана грали три різних актори (Пилип Іллєнко, Богдан Ступка, Сергій Марченко) у різні періоди його життя. “Але насправді зміна акторів на екрані мотивована зовсім не історичними, а виключно естетичними причинами, - писав вже згадуваний кінознавець В. Симак. - Під час однієї сцени Мазепа може змінювати обличчя кілька разів. Режисер постійно натякає на багатогранність свого героя, заперечуючи можливість вмістити Мазепу у будь-яку усталену історичну концепцію...” [15]. На нашу думку, задум Ю. Іллєнка варто розглядати у площині як “історичного”, так i “метафоричного” кіно, в якому головний принцип дії - "метарежисура" - власна система режисури Ю. Іллєнка (згодом увійшла до теоретичних програм Київського національного університету театру, кіно і телебачення ім. І. Карпенка-Карого), сутність якої полягала у намаганні постановнка керувати свідомістю глядача. Причому даний режисерський підхід повністю заперечував будьяке нав'язування глядачеві усталеного трактуваня історичних подій.

Якщо говорити про фільм “Мамай”, то варто наголосити, що він відноситься до кінемаграфа вишукано мистецького, арт-хаузного, і $є$ власною відповіддю його постановників на питання: чому фольклорний персонаж, легендарний козак Мамай має ім'я хана татарської орди. У центрі сюжету три лінії розповіді: “Дума про трьох братів азовських" (за мотивом однойменної української пісні XVI століття); “Пісня дервіша про трьох доблесних мамлюків” (в основі - тюркський епос про трьох братів татар, які воювали найманцями в різних арміях, але залишли службу як тільки почули плач Золотої Співочої Колиски); історія про татарськужінку (сюжет вигаданий самим О. Саніним), яка знайшла в степу пораненого козака, вилікувала його, а потім стала його дружиною [9], [14].

Романтична версія воєнних подвигів українського полководця Б. Хмельницького стала центром сюжету однойменного фільма М. Мащенка (оператор-С. Борденюк, композитор М. Чемберджі). У фільмі детально показано облогу козаками поляків у місті Збараж і динамічну битву біля містечка Зборова (у батальних сценах взяло участь близько 30000 осіб). Головний герой Хмельницький, постає у фільми сильною і темпераментною людиною, саме таким, яким його описують історичні хроніки. Новим у трактуванні гетьмана стала неоднозначність його образу (приміром, вірить у перемогу, але досить лояльно ставиться до супротивника і навіть виявляє милосердність до польського короля, 3 яким щойно воював тощо).

Серед кінострічок початку 2000-х років варто виділити окрему групу фільмів філософського спрямування, в яких спостерігаються важливі елементи фольклорної кінопоетики. Зокрема, поетична краса і філософська багатозначність складають основу кінострічок: “Філософія” (реж. А. Пасікова, 2006), “ТойХтоПройшовКрізьВогонь" (реж. М. Іллєнка, 2010), “Брати. Остання сповідь” (реж. В. Трофименко, 2013).

Сільські диваки, люди "не від світу цього" стали героями кінострічки режисера А. Пасікової “Філософія”. У фільмі практично відсутня сюжетна лінія: в центрі їі уваги двоє сільських дядьків, які не завжаючи на свій поважний вік не втратили віри у силу життя в усіх його проявах (приміром, один із них - нереалізований “талант”, сільський музикант, що грає на місцевих похоронах, сподівається вступити до консерваторії). Проте обидва приречені на самотність у загубленому селі через надмірне вживання алкоголю. Кінокартина виявляє прагнення ії авторки - А. Пасікової зняти будьяку перешкоду між реальним життям і фільмом. Кінознавець Л. Брюховецька слухно відзначила, що кінострічка "претендує на замальовку 3 натури, на шматок необробленої реальності, в яку автори стрічки разом 3 акторами не бажають втручатися чи виявляти своє ставлення до зображувального. Даючи тим самим глядачеві можливість самому розібратися з побаченим" $[3,86]$

Драматично напруженим та емоційно наповненим зверненням до етнічної пам'яті українців став фільм режисера М. Іллєнка “ТойХтоПройшовКрізьВогонь” (сценарій-Д. Замрій, К. Коновалов, оператор - О. Кришталтович, художник-Р. Адамович, композитор-В. Гронський, 2010). У змісті кінокартини історія реальної людини - льотчика, героя Радянського Союзу Івана Доценка, який після втечі з німецького полону потрапив до ГУЛАГу. Стилістика “фольклорного” розкривається в режисера у зверненні до містичного: він демонструє загадкове явище - передання на відстані внурішньої енергії від однієї людини до іншої (в епізодах, де розкривається любовний трикутник між заарештованим льотчиком, його дружиною та співробітником НКВС). Містичне й фантастичне водночас перегукується 3 психологічною достовірністю багатьох епізодів життя політв'язнів. 
Кінокартину “Брати. Остання сповідь” режисерки В. Трофименко (оператор-Я.Пілунський) було знято у Карпатах. У центрі уваги режисера - історія двох братів, які доживають вік у непримиренній ворожнечі через єдину кохану жінку, яка вже давно померла. Полегшити смерть одного з них - тяжко хворого діда намагається мандрівниця (Н. Половинка), яка випадково потрапила до села. Постать останньої режисер уводить в тінь: про неї лише відомо, що вона ходить по церквах, де розповідає про засади вчення Христа, має природний дар чинити добро. Вже згадувана кінознавець Л. Брюховецька в одному із своїх критичних відгуків на фільм досить слушно порівняла братів зі стрічки “Брати. Остання сповідь" з іншими героями - братами Дзвонарями "Білого птаха 3 чорною ознакою": "Поступ більше, як на півстоліття - і вже братів Дзвонарів роз'єднала класова битва, що пронеслася над цією прекрасною землею. Брати 3 фільму Трофименко народилися і жили в мирний час, але знов ворожнеча, хоча причин немає [...]. Ізольованість, відсутність людей дозволяють провести лабораторно чистий досвід, заглянути у світ без кохання, у життя без сенсу" [3, 251 - 252].

Метафоричне, відсторонене осмислення дійсності можна також побачити у короткометражних фільмах молодих українських режисерів Д. Сухолитка-Сабчука, Р. Сінчука, М. Вроди, I. Правили, Р. Бондарчука, I. Канівця тощо. Розглянемо кілька кінострічок як приклад.

У короткометражці“Коріння”режисерД. СухолиткоСабчук (2009) звертається до тематики осягнення людиною минулого та майбутнього власного роду. Фільм знято за мотивами твору Г. Тютюнника “Дикий”, де тоненька мотузка стає метафоричним порівнянням із людським життям (запозичення насамперед вказує на усну народну творчість, де нитка, мотузка, стрічка - це шлях життя, лінія буття людини). У фільмі :"Борода" (2011) режисер презентував побутову культуру одного $з$ сіл на Західній Україні (зйомки проводилися у селах Стецівка, Стецева, Підвисоке, Ясенів Снятинського p-ну Івано-Франківської обл.). Центр драматичного конфлікту вибудовується навколо бороди, яка виступає симоволом самотності голового героя: чекаючи на повернення 3-за кордону доньки-заробітчанки, він розмірковує про подальшу долю родини й демонструє оригінальну народну філософію щодо спадкоємності поколінь.

Р. Сінчук поставив 2012 року за оповіданням В. Підмогильного (сценарій Л. Череватенка) короткометражну кінострічку “Гайдамаки", де розкрив внутрішній світ розчарованого у самому собі юнака-гімназиста. За змістом, станній намагається покінчити із життям шляхом вербування у діючю армію в гайдамацький загон. Лейтмотивом кінотвору стає твердження письменника: думки про смерть і реальність власне смерті - різнополярні речі. Проблема реальних відчутів людини перед обличчям справжньої небезпеки й потенційної загрози для життя передано режисером й автором досить глибоко й правдиво.

Філософська думка про відстань між людським буттям та смертю стала лейтмотивом комедії режисера I. Кравчишина "Політ золотої мушки" (назва виступає кінометафорою: політ мушки - тобто дуже коротке). В центрі уваги авторів фільму, знятого за оповіданнями Б. Волошина, повсякдення провінційного життя маленького містечка серед Карпатських гір (герої розмовляють гуцульським діалектом). Кінострічку побудовано як окремі інтермедії, в яких масові сцени змінюються сольними i дуетними "виходами" кіногероїв. Яскраво знято колоритні епізоди гуцульського весілля із застіллям, автентичною музикою і танцями (відомо, що у фільмі знялися справжні весільні музики). Комічні ситуації вибудовуються й навколо смерті головного героя (події, що відбуваються з покійником й навколо нього). Отже, шлях до фольклорної образності крізь призму комедійних ситуацій було обрано режисером через побут і звичаї гуцулів.

Проникливою картиною настрою, що апелює насамперед до відчуттів стала кінострічка режисера Н. Кошман (учениця відомого українського кінорежисера В. Кісіна) “Рай” (2006), яка розповідає про народну художницю-аматорку Поліну Райко. Про неї відомо, що вона перетворила на "рай” власну хату, розмалювавши стіни й стелю унікальними розписами. Зйомки проводилися на натурі у місті Гола Пристань, що на Херсонщині. По-своєму трагічна і водночас пересічна доля жінки постає зі спогадів сестри Марії Свістухіної та односельців: воєнна юність, тяжка фізична праця, чоловік залежний від алкоголю, несподівана гибель улюбленої доньки та ув'язнення сина, що став на шлях батька, життя на мізерну пенсію і зрештою - смерть. I поряд із всім цим - світлі й піднесені фрески: Ісус Христос, Діва Марія, автопортрети щасливої жінки та іiі родини в оточенні чарівних птахів, звірів, казкових рослин. Щоб підкреслити автентичність тла кінокартини, режисерка використала спів народної співачки Рахілі Руснак та імпровізації на українські народні пісні Нелі Бикової [7, 56 - 57].

2008 року вийшла документальна стрічка Г. 
Яровенко “Фієста”. В центрі режисерської уваги опинявся колишній учитель (викладач англійської та іспанської мов) 3 села Великий Хутір Драбівського району Черкаської області Михайло Коваль. Ця непересічна людина зацікавила творців кінострічки власним прагненням збирати пісенний фольклор свого краю, виконувати його, акомпануючи собі на бандурі та інших народних інструментах. Живописніть кінотвору підкреслювали широкі панорамні зйомки краєвидів села, селянських подвір’їв, і навіть худоби. В об'єктив оператора потрапили також юні колядувальники, вбрані у новорічні костюми відповідно до персонажів святкового вертепу. Впродовж фільму поряд із українським фольклором лунає 3 вуст героя й простенька іспанська пісенька “Фієста”, яка звучить невимушено й безперечно викликає симпатію у глядача. Артистичній і талановитій людині все вдається легко, - резюмує Г. Яровенко. Творчість простої людини вселяє віру у глибинність духовної сили українського народу.

Власну інтерпретацію долі (світоглядної драми) видатного українського письменника Миколи Гоголя запропонував режисер та автор сценарію фільму “Загублений рай” - Р. ПлаховМодестов (оператор О. Кабаченко, художник С. Якутович). Кіноматографічний матеріал складають ілюстрації відомих художників до творів письменника, фрагменти 3 фільмівекранізацій, дикторський текст за кадром тощо. Сюжет розгортається через постать самого Гоголя, людей його кола та літературних персонажів його творів. У фільмі йдеться про творчу кризу письменника, яку, на думку Р. ПлаховаМодестова, спричинила відірваність від українського автентичного коріння: письменник, який зосереджується у власних творах навколо духовної культури рідної землі (в тому числі й усної народної творчості), одразу втрачає здатність писати і жити, як тільки починає шукати рай у чижих землях.

Цікаво, що продовженням лінії “Загубленого раю” стала інша документальна стрічка Р. ПлаховаМодестова - "Підніміть мені повіки" (оператор - М. Радовський, художник - С. Якутович, композитор - С. Крутіков, 2013), присвячена пізнанню психології Гоголя-письменника. Зокрема, режисер обмірковує думку Гоголя про два шляхи, через які гріх проникає у людьке життя - жінку та мистецтво. Причому право закадрового монологу здобуває сам письменнник через персонажів власних творів - Хому Брута (“Вій”) та Чарткова (“Портрет”). Першій літературний герой допомагає зрозуміти страх самого письменника перед жінками, їхньою спокусливістю та містичною силою, жертвами якої стають чоловіки. Другий герой - одержимий творчістю, пророкує власну долю Гоголя, який не зміг витримати психологічного стресу через творче безсилля рівноцінне фізичній смері. Візуальна поетика кінострічки підкреслена портретами, замальовками, макетами стилізованих рукописів, анімаційними ілюстраціями, виконаними С. Якутовичем.

Підсумовуючи викладене вище, наголосимо на наступних висновках. 2000-і роки характеризувалися появою в українському прокаті кінокартин, в яких спостерігалися важливі елементи кінопоетики (зокрема, автентичний спів, танці, інструментальна музика, різноманітні локальні діалекти української мови, живописний відеоряд тощо), а також кінострічки за мотивами літературних творів на історичну тематику. Філософське осмислення оточуючого світу, яке сягало корінням у джерела народної мудрості, спостерігалося у короткометражних фільмах та вітчизняній документалістиці, автори якої продовжили розвиток стилістики української фольклорної кіношколи середини ХХ століття.

Підкреслимо, що вивчення фольклорної кіностилістики 3 кожним роком набуває потужних обертів у сучасному вітчезняному кінематографі, не може обмежуватися даною науковою розвідкою і потребує подальшої кінознавчої уваги 3 оприлюдненням здобутих результатів у спеціалізованних наукових виданнях з історії вітчизняного та світового кіномистецтва.

\section{ЛІТЕРАТУРА}

1. Брюховецька Л. Війна культур чи загроза асиміляції? Українське поетичне кіно як фактор національного самоствердження. Наукові записки НаУКМА. Теорія та історія культури. 2008. T.75. C. $77-84$.

2. БрюховецькаЛ.Кіно в Україніпершого десятеріччя незалежності. Кіно-Театр. 2001. №5. С. 4-5.

3. Брюховецька Л. “Солодке” життя найважливішого з мистецтв: 2001-2015. Київ, 2015. 272 с.

4. Бучко Р. Кінематографічна картина світу i місце України в ній. Діалог культур: Украӥна у світовому контексті. Мистеитво $і$ освіта. Львів, 1998. С. 415-421.

5. Дяченко С. Український євроформат. КіноКоло. 2003. № 20. С. 109.

6. Зубавіна I. Кінематограф незалежної України: тенденції, фільми, постаті, Київ: Ін-т проблем сучасного мистецтва, 2007. 296 с.

7. Кандинська В. Зворушливість буття. Украӥнський журнал. 2007. № 11. С. 56-57. 
8. Капельгородська Н. Ренесанс вітчизняного кіно: Нотатки сучасниці. Київ, 2002. 164 с.

9. Кипиани В. Поводырь, кино и кобзари. Історична правда. 2014. 15 листопада. URL: https://nv.ua/opinion/kipiani/povodyr-kino-i-kobzari20526.html (дата звернення 27.06.2019)

10. Кузьмук В. “Катакомбний” період українського кіно. Мистецьккі обрії 2000. Київ, 2002. Вип. 3. C. 227-231.

11. Мусієнко О. Обгрунтування нового погляду на історію кіно України. Мистецькі обрї’2000. Київ, 2002. Вип. 3. С. 186-193.

12. Поліщук Т. "Чорна рада" знімається в борг. Режисер Микола Засєєв-Руденко закінчує зйомки історичної епопеї. День. 1999. 30 вересня. C. 4.

13. Рутковський О. Еволюція української кінодумки у пострадянський період. Мистецькі обрії 2000. Київ, 2002. Вип. 3. С. 202-213.

14. Санін О. Хто боїться Мамая? Кіно-коло. 2003. 15 лютого. URL: https://www.kinokolo.ua/ articles/67/

15. Симак В. Молитва проти анафеми. Релігія в Україні. 2010. 11 листопада. URL: https:// www.religion.in.ua/main/6743-molitva-protianafemi.html (дата звернення 24.09.2019).

\section{REFERENCES}

1. Briukhovetska, L. (2008). Viina kultur chy zahroza asymiliatsii? Ukrainske poetychne kino yak faktor natsionalnoho samostverdzhennia [The culture war or the threat of assimilation? Ukrainian Poetic Cinema as a Factor of National Affirmation]. National University "Kyiv-Mohyla Academy" Scientific Notes. The theory and history of culture, Vol. 75. pp. 77-84. [in Ukrainian]. pershoho desiaterichchia nezalezhnosti [Cinema in Ukraine of the first decade of independence]. Cinema, no. 5, pp. 4-5. [in Ukrainian].

3. Briukhovetska, L. (2015). "Solodke" zhyttia naivazhlyvishoho $z$ mystetstv: 2001-2015 ["Sweet" life of the most important of the arts: 20012015]. Kyiv, 272 p. [in Ukrainian].

4. Buchko, R. (1998). Kinematohrafichna kartyna svitu i mistse Ukrainy v nii [Cinematic picture of the world and Ukraine's place in it]. Dialogue of cultures:
2. Briukhovetska, L. (2001). Kino v Ukraini

Ukraine in a global context. Arts and education. Lviv, pp. 415-421. [in Ukrainian].

5. Diachenko, S. (2003). Ukrainskyi yevroformat [Ukrainian Euroformat]. Film-Circle, no. 20, 109 p. [in Ukrainian].

6. Zubavina, I. (2007). Kinematohraf nezalezhnoi Ukrainy: tendentsii, filmy, postati [Cinematography of independent Ukraine: trends, films, figures]. Kyiv, 296 p. [in Ukrainian].

7. Kandynska, V. (2007). Zvorushlyvist buttia [Touchability of being]. Ukrainskyi zhurnal, no. 11, pp. 56-57. [in Ukrainian].

8. Kapelhorodska, N. (2002). Renesans vitchyznianoho kino: Notatky suchasnytsi [National Cinema Renaissance: Contemporary Notes]. Kyiv, 164 p. [in Ukrainian].

9. Kypyany, V. (2014). Povodyr, kyno y kobzary. Istorychna pravda [Guide, movies and kobzari]. Available at: https://nv.ua/opinion/kipiani/povodyrkino-i-kobzari-20526.html> (accessed 27 June 2019).

10. Kuzmuk, V. (2002). "Katakombnyi” period ukrainskoho kino ["Catacomb" period of Ukrainian cinema]. Artistic Horizons'2000. Kyiv, vol. 3, pp. $227-$ 231. [in Ukrainian].

11. Musiienko, O. (2002). Obgruntuvannia novoho pohliadu na istoriiu kino Ukrainy [Substantiation of a new look at the history of Ukrainian cinema]. Artistic Horizons'2000. Kyiv, vol. 3, pp. 186-193. [in Ukrainian].

12. Polishchuk, T. (1999). "Chorna rada" znimaietsia v borh. Rezhyser Mykola ZasieievRudenko zakinchuie ziomky istorychnoi epopei ["Chorna rada" is debited. Director Mykola ZaseyevRudenko ends filming of a historical epic]. Day, vol. 30 September, 4 p. [in Ukrainian].

13. Rutkovskyi, O. (2002). Evoliutsiia ukrainskoi kinodumky u postradianskyi period [The evolution of Ukrainian cinema thought in the post-Soviet period]. Artistic Horizons'2000. Kyiv, vol. 3, pp. 202-213. [in Ukrainian].

14. Sanin, O. (2003). Khto boitsia Mamaia? [Who's afraid of Mamaia?]. Available at: https:// www.kinokolo.ua/articles/67/ (Accessed 21 Sept. 2019).

15. Symak, V. (2010). Molytva proty anafemy. Relihiia v Ukraini [Prayer against anathema]. Available at: https://www.religion.in.ua/main/6743molitva-proti-anafemi.html (Accessed 24 Sept.2019).

Стаття надійшла до редакції 17.10.2019

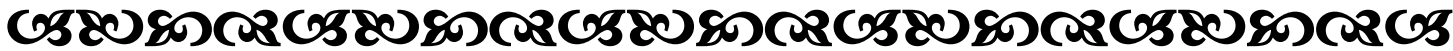

"ТІаємниия успіху в житті полягає в тому, щоб бути готовим скористатись із слушної нагоди, коли вона настане”.

$\pi^{\prime \prime}$ єр Бауст

браниузъжий лексикограб $і$ поет 